\title{
Two new, easternmost species of the millipede genus Anamastigona Silvestri, 1898 from Israel and the Caucasus (Diplopoda: Chordeumatida: Anthroleucosomatidae)
}

\section{Ава новых, самых восточных вида диплопод рода Anamastigona Silvestri, 1898 из Израимя и с Кавказа (Diplopoda: Chordeumatida: Anthroleucosomatidae)}

\author{
S.I. Golovatch ${ }^{1} \&$ S.E. Makarov ${ }^{2}$ \\ С.И. Головач ${ }^{1}$, С.Е. Макаров ${ }^{2}$
}

\footnotetext{
${ }^{1}$ Institute for Problems of Ecology and Evolution, Russian Academy of Sciences, Leninsky prospekt 33, Moscow 119071 Russia.

${ }^{1}$ Институт проблем экологии и эволюции РАН, Ленинский проспект, 33, Москва 119071 Россия.

${ }^{2}$ Institute of Zoology, Faculty of Biology, University of Belgrade, Studentski Trg 16, Belgrade 11000 Serbia.

${ }^{2}$ Институт за Зоологију, Биолошки факултет, Универзитет у Београду, Београд 11000 Србија.
}

KEY WORDS: Diplopoda, Anamastigona, taxonomy, new species, Israel, Caucasus, Abkhazia.

КЛЮЧЕВЫЕ СЛОВА: Diplopoda, Anamastigona, таксономия, новые виды, Израиль, Кавказ, Абхазия.

ABSTRACT. Two new species of the Mediterranean genus Anamastigona are being described: A. terraesanctae sp.n. from Israel, and $A$. mauriesi sp.n. from Abkhazia, Caucasus. At present, both of these species are the easternmost representatives of this genus, while the one from Israel is simultaneously the first and southeasternmost member of the order Chordeumatida in the diplopod fauna of the entire Near East. The new species from Abkhazia is the first record of Anamastigona in the Caucasus, one of the long acknowledged centres of anthroleucosomatid generic and species differentiation globally. The following new synonymy is formalized: Anamastigona aspromontis (Strasser, 1970) $=$ A. meridionalis Silvestri, 1898, syn.n., and Anamastigona halophila $($ Verhoeff, 1940$)=A$. bilselii $($ Verhoeff, 1940), syn.n . (the valid names in the right).

РЕЗЮМЕ. Описаны два новых вида средиземноморского рода Anamastigona: A. terraesanctae sp.n. из Израиля и A. mauriesi sp.n. из Абхазии (Кавказ). Оба эти вида - пока самые восточные представители рода, а вид из Израиля еще и первый, и самый юго-восточный представитель отряда Chordeumatida среди диплопод фауны Ближнего Востока. Новый вид из Абхазии - это первая регистрация рода Anamastigona на Кавказе, который, как давно известно, представляет собой один из мировых центров родового и видового разнообразия Anthroleucosomatidae в мире. Формализована следующая новая синонимия: Anamastigona aspromontis (Strasser, 1970) = A. meridionalis Silvestri, 1898, syn.n., и Anamastigona halophila (Verhoeff, 1940) $=$ A. bilselii (Verhoeff, 1940), syn.n. (валидные названия справа).

\section{Introduction}

The Mediterranean millipede genus Anamastigona Silvestri, 1898 is the largest and most widespread in the large Holarctic family Anthroleucosomatidae. This genus has hitherto contained 14-17 accepted species, arranged below more or less according to their distributions from west to east (http://www.faunaeur.org/ index.php):

- A. pulchella (Silvestri, 1894), the type-species, originally described as Craspedosoma pulchellum Silvestri, 1894, with one junior synonym, ranging from southern France, as well as southern and central Italy to northern Ireland, Madeira, Portugal and central Germany;

- A. hispidula (Silvestri, 1895), with several junior synonyms, from southern and central Italy;

- A. meridionalis Silvestri, 1898, with a junior synonym, from Sicily, Italy;

- A. aspromontis (Strasser, 1970) (NB: suspected to be a junior synonym of $A$. meridionalis, but no formal synonymy advanced), from Calabria, Italy;

- A. radmani Makarov, T. Rada, B. Rada, Tomić, Mitić \& Ćurčić, 2007, from Croatia;

- A. albanensis Mauriès, Golovatch \& Stoev, 1997, from Albania;

- A. alba (Strasser, 1960) (NB: at present suspected to represent a genus of its own);

- A. falcata (Gulička, 1967);

- A. delcevi (Strasser, 1973) (NB: sometimes misspelled as "deltcevi");

- A. lepenicae (Strasser, 1973), all four latter species from Bulgaria; 
- A. bilselii (Verhoeff, 1940), from eastern Greece, Bulgaria and western Turkey;

- A. pentelicona (Verhoeff, 1925) (NB: sometimes misspelled as "pentelonica" or "penteliconica"), from Attika, Greece;

- A. hauseri (Strasser, 1974), from Lefkas Island and Cephalonia, Greece;

- A. mediterranea Ćurčić, Makarov \& Lymberakis, 2001;

- A. penicillata (Attems, 1902), both latter species from Crete, Greece;

- A. matsakisi Mauriès \& Karamaouna, 1984, from Naxos Island, Cyclades, Greece;

- A. halophila (Verhoeff, 1940) (NB: suspected to be a junior synonym of $A$. bilselii, but no formal synonymy advanced), from northwestern Anatolia.

At least two species groups are distinguished, based on the structure of the posterior gonopods [Makarov et al., 2007]. Thus, a few, mainly Bulgarian species show these structures highly derived, with telopodites totally suppressed and the external coxal processes elongate as opposed to the conditions observed in the remaining congeners.

Relevant literature concerning individual species, both original descriptions and/or later redescriptions, is quite diverse [e.g., Attems, 1902; Verhoeff, 1925, 1940; Strasser, 1957/58, 1960, 1962, 1970b, 1970c, 1973, 1974, 1975; Mauriès, 1960; Mauriès \& Karamaouna, 1984; Mauriès et al., 1997; Ćurčić et al., 2001; Makarov et al., 2007; Lindner et al., 2010], but the most recent and useful review of the family Anthroleucosomatidae, as well as a key to all of its 22 genera and $>40$ accepted species, is that by Ćurčić et al. [2008]. It is this latter review that makes a new key to the species of Anamastigona unnecessary. Moreover, we formalize here the following new synynymy first advanced in Ćurčić et al. [2008]: Anamastigona aspromontis (Strasser, 1970) = A. meridionalis Silvestri, 1898, syn.n., and Anamastigona halophila (Verhoeff, 1940) $=A$. bilselii (Verhoeff, 1940), syn.n., the valid names being in the right. Neither of these two junior subjective synonyms can readily key out from their respective senior synonyms.

Our paper puts on record another two species, both new and currently representing the easternmost congeners. In addition, the new species from Israel is simultaneously the first and southeasternmost member of the order Chordeumatida in the diplopod fauna of the entire Near East, whereas the new species from Abkhazia is the first record of Anamastigona in the Caucasus, a long acknowledged centre of anthroleucosomatid generic and species differentiation globally.

The following abbreviations are employed here, following Spelda [2001]:

CIX - macrochaetal index (distance between exterior and median macrochaetae divided by distance between interior and median macrochaetae).

MA - macrochaetal angle (formed between the arm from the median and exterior macrochaetae and that between the median and interior macrochaetae).
MIX - median index (distance between interior macrochaeta and axial suture divided by distance between interior and median macrochaetae).

PIX - paratergal index (ratio of difference between metatergite width and prozonite width to 2 paratergite lengths).

ZMTA - Zoological Museum, University of Tel Aviv, Israel.

ZMUC - Natural History Museum, University of Copenhagen, Denmark.

ZMUM - Zoological Museum, State University of Moscow, Russia.

\section{Taxonomic part}

Anamastigona terraesanctae sp.n. Figs 1-30.

MATERIAL. Holotype $\sigma^{7}$ (ZMTA), Israel, Upper Galilee, Nahal Keziv, pitfall trapping, 17-31.01.1999, leg. M. Finkel.

Paratypes: $1+$ (ZMTA), $2 \sigma^{\top} \sigma^{7}, 1$ juv. (ZMUM), same locality, dates and collector, together with holotype; $1 \sigma^{7}$ (ZMUM), Upper Galilee, Birya N of Safed, 32 59'46”N, 35'30'29'E, Pinus brutia plantation, ca 800 a.s.1., 27.04.2009; $1 \sigma^{7}$ (ZMTA), same locality, 11.03.2009; 1 ○ (ZMTA), same locality, 24.11.2009, all leg. Y. Mandelik; 1 ○ (ZMUC), Allonim S of Mt Carmel, 12.02.1975, leg. M. Warburg; 1 + 4 juv. (ZMUM), Mt Carmel, Nahal Oren, forest litter, $03 \&$ 06.03.2003; $1 \sigma^{7}$ (ZMTA), $1 \sigma^{7}$ (ZMUM), Mt. Meron, N slope, ca 1,000 m a.s.1., Quercus forest, litter, 06.03.2003, all leg. S. Golovatch; 3 juv. (ZMMU), Judean Mts, Zharya, pitfall traps, 11.2001; $1 \sigma^{7}, 1$ (ZMUM), Adolam Nature Reserve near Beit Gurvin, pitfall traps, 11.2001; $1 \sigma^{7}$ (ZMTA), $1 \sigma^{7}$ (ZMUM), Sansan near Mata, pitfall traps, 11.2001, all leg. Y. Mandelik.

NAME. To reflect the Holy Land as the region of origin.

DIAGNOSIS. Difffers from congeners in the reversed proportions of the angio- and colpocoxites of the posterior gonopods, in which the colpocoxite $(\mathbf{k})$ is uncharacteristically membranous and considerably shorter than the coxite or angiocoxite (see key in Ćurčić et al. [2008]).

DESCRIPTION. Length of adults $8.5-10.0 \mathrm{~mm}$, width and vertical diameter $1.0 \mathrm{~mm}$ (body subcylindrical). Holotype ca $9.0 \mathrm{~mm}$ long. Coloration (Figs $1 \& 2$ ) usually marbled grey-brown to dark brown, more intense in anterior third of body, often with only wide paramedian stripes and region below paraterga infuscate, leaving axial suture and paraterga more flavous, light brown.

Body segments 30 (29 pleuroterga, including one apodous, + telson) in both sexes. Tegument smooth, only in places very finely striolate, dull to poorly shining (Figs $1 \& 2$ ); texture microalveolate to microstriolate. Head with 15-20 blackish ocelli arranged in five horizontal rows: $5(6)+5(4)+4(3)+3(2)+2(1)$, counting from below; lenses convex and translucid. Head densely setose/pubescent (Fig. 1); frons either evidently flattened, sometimes even with a slight impression before interantennal isthmus $\left(\sigma^{7}\right)$, or slightly and regularly convex (+). Antennae (Figs 1 \& 16) short, slightly clavate. Labrum with three typical anteromedian teeth; labral setae shorter, 5+5; supralabral setae longer, 


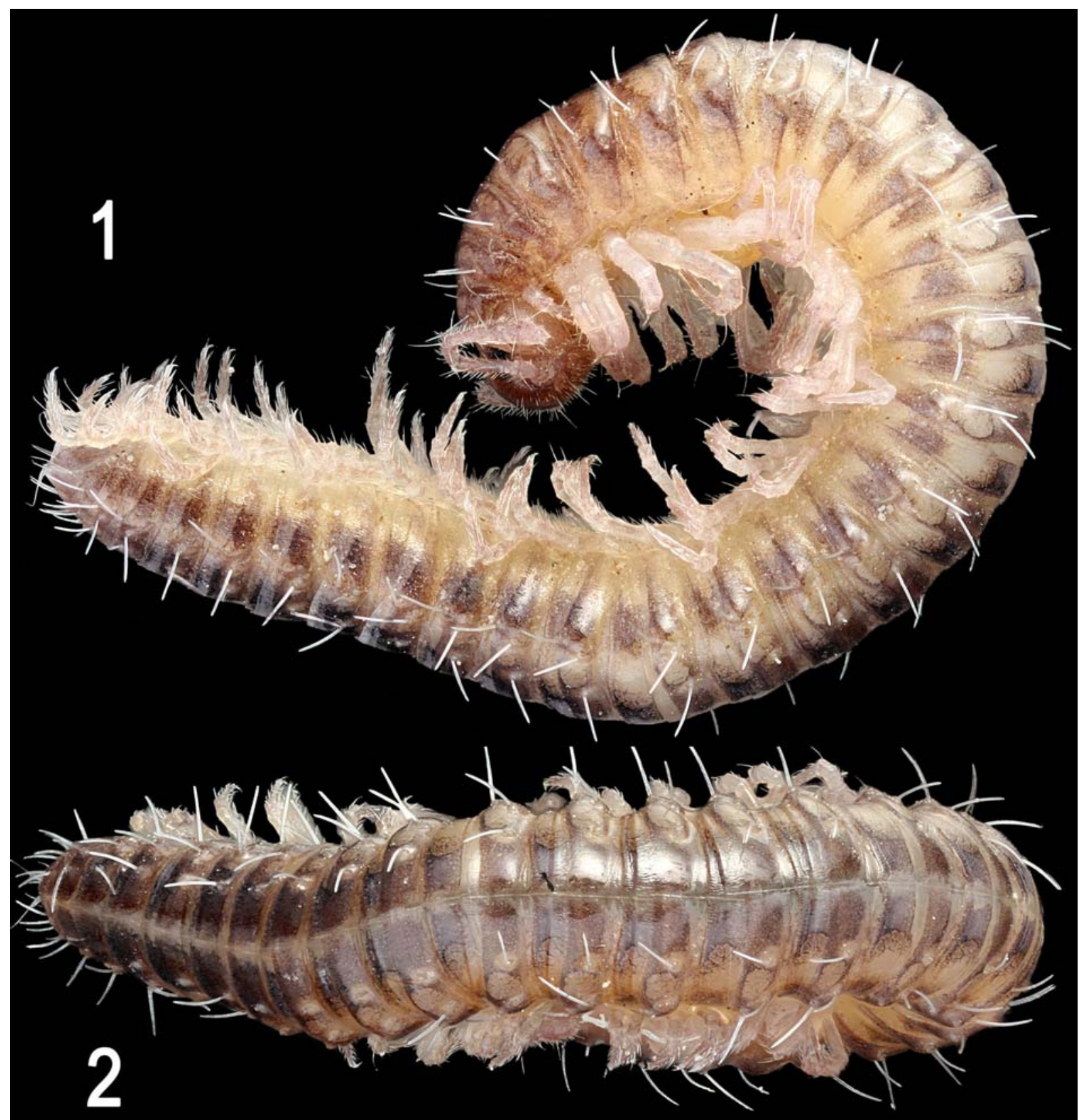

Figs 1-2. Habitus of Anamastigona terraesanctae sp.n., $0^{\top}$ paratype from Birya, lateral and dorsal views, respectively. Photographs by K. Makarov, not to scale

Рис. 1-2. Anamastigona terraesanctae sp.n., паратип О7 из Birya, сбоку и сверху, соответственно. Фотографии К. Макарова, без масштаба.

2(3)+2(3). Gnathochilarium (Fig. 3) with a large and triangular promentum; stipites with several (sub)lateral setae growing increasingly longer apicad; each lamella lingualis with a longitudinal row of four setae, basalmost of which being shortest.

In width, either collum $<<$ head $=$ segment 3 or $4<$ $2(3)<5=8-22(23)<6=7\left(\sigma^{7}\right)$, or collum $<<$ head $=$ segment 3 or $4<2(3)<5-22(23)(+)$; after segment 22 or 23 , body gradually and increasingly narrowed towards telson.
Axial suture well-developed, thin. Stricture between pro- and metazona clearly visible, rather wide and shallow. Paraterga small dorsolateral swellings/shoulders, not set off by peritremata, rather regularly rounded in dorsal view, gradually and increasingly reduced from segment 22 or 23 , totally disappearing on segments 28 and 29. Metatergal setation 3+3, typical, macrochaetae rather long and thick, pointed, placed on small knobs. Interior macrochaeta well removed from exterior and median ones, the latter longest, both of the latter only 

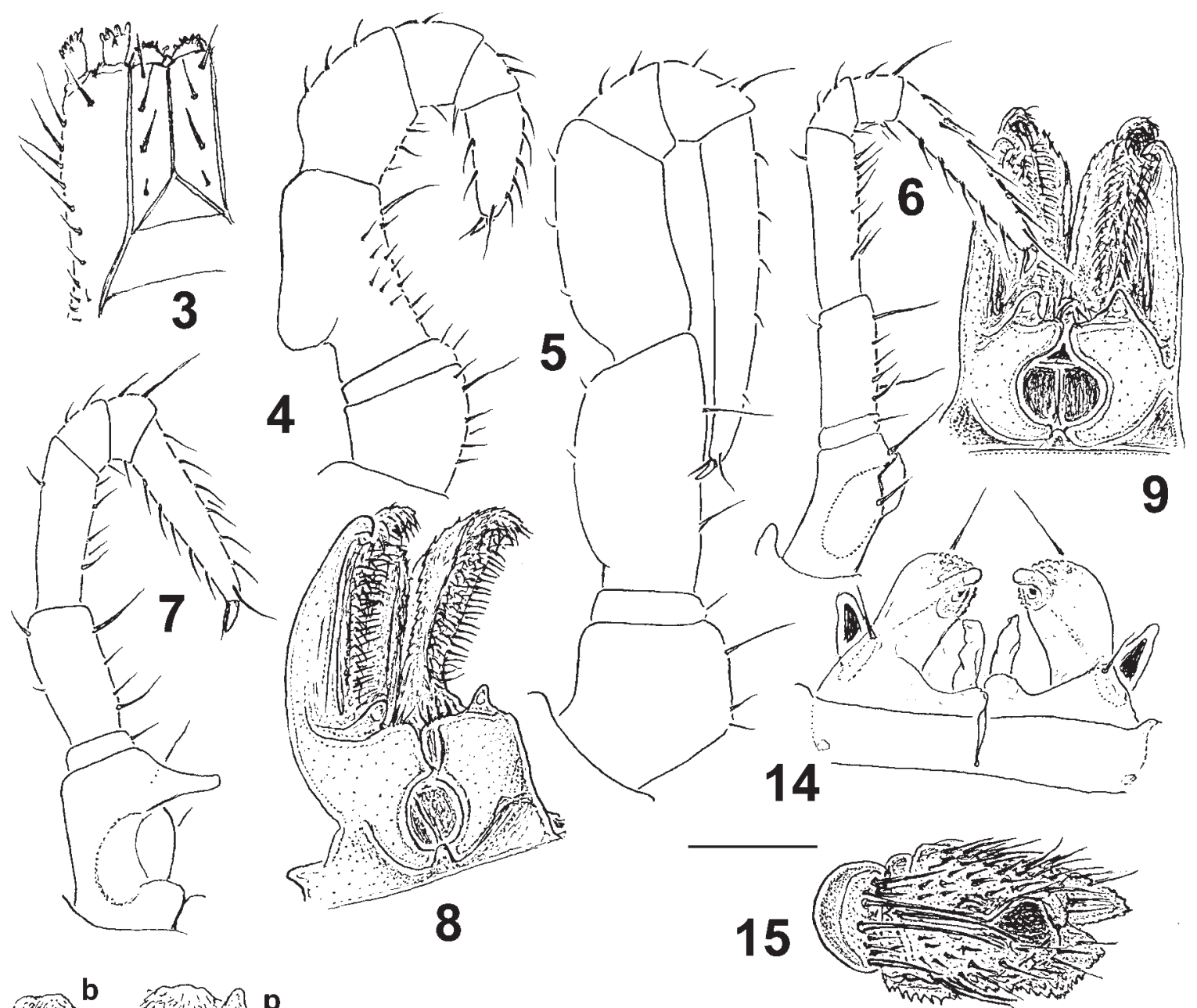

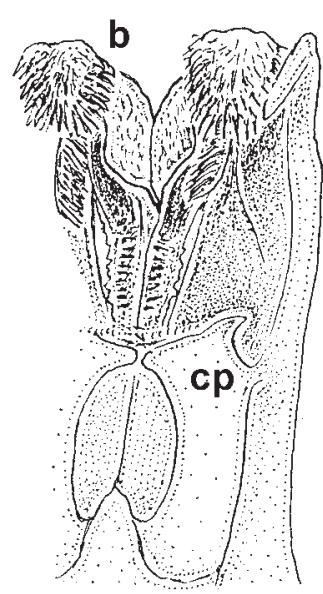

10

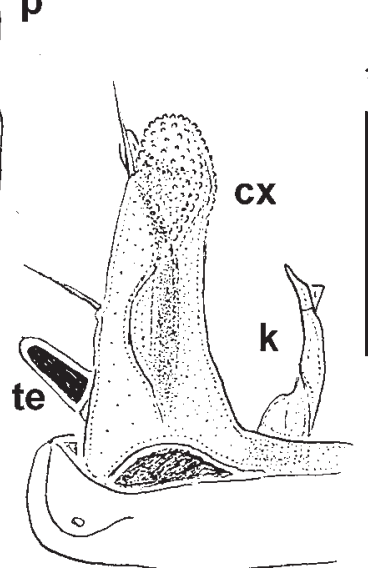

13

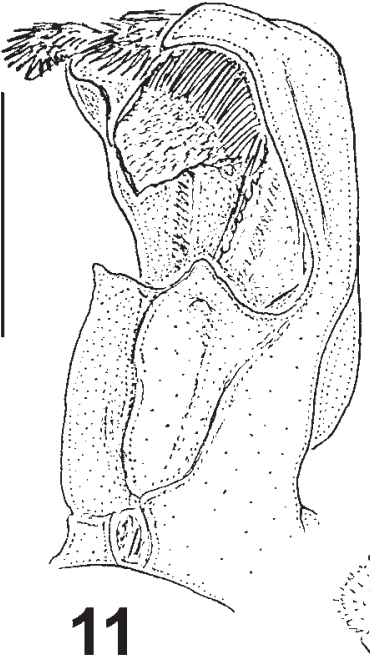

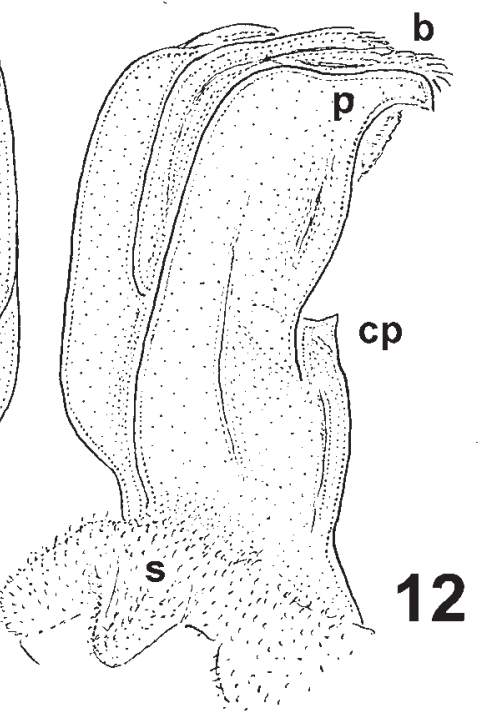

Figs 3-15. Anamastigona terraesanctae sp.n., $\bigcirc^{7}$ paratypes from Sansan $(3-9,14)$ and Nahal Keziv $(10-13)$, and $q$ paratype from Adolam (15): 3 - gnathochilarium, ventral view; 4 - leg 4; 5 - leg 7; 6 - leg 10; 7 - leg 11;8-12 — anterior gonopods, caudolateral, caudal, caudal, caudolateral and sublateral views, respectively; $13 \& 14$ - posterior gonopods, caudal and front views, respectively; 15 vulva, subventral view. Scale bars $0.2 \mathrm{~mm}$.

Рис. 3-15. Anamastigona terraesanctae sp.n., паратипы $0^{7}$ из Sansan $(3-9,14)$ и Nahal Keziv $(10-13)$, и паратип + из Adolam (15): 3 - гнатохилярий, снизу; 4 - нога $4 ; 5$ - нога $7 ; 6$ - нога $10 ; 7$ - нога $11 ; 8-12$ - передние гоноподы, соответственно сзади и сбоку, сзади, сзади, сзади и сбоку и почти сбоку; 13 и 14 - задние гоноподы, соответственно сзади и спереди; 15 вульва, почти снизу. Масштаб 0,2 мм. 


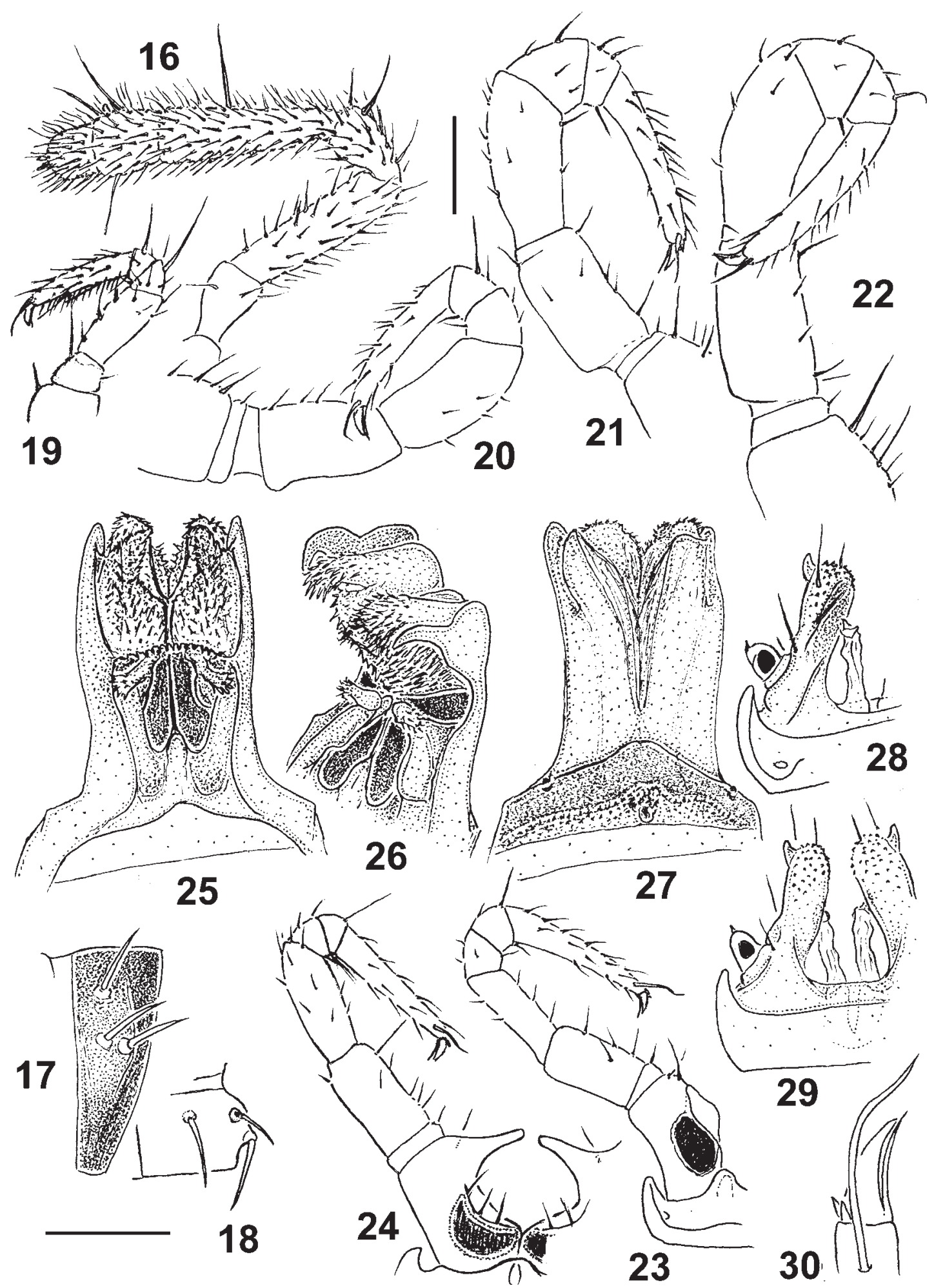

Figs 16-30. Anamastigona terraesanctae sp.n., $O^{7}$ paratype from Mt Meron: 16 - antenna; 17, 18 - metatergum 15, lateral and dorsal views, respectively; $19-\operatorname{leg} 1 ; 20-\operatorname{leg} 5 ; 21-\operatorname{leg} 6 ; 22-\operatorname{leg} 7 ; 23-\operatorname{leg} 10 ; 24-\operatorname{leg} 11 ; 25-27-$ anterior gonopods, caudal, sublateral and front views, respectively; 28,29 — posterior gonopods, caudal and front views, respectively; 30 — enlarged end of midbody leg. Scale bars $0.5(17-18)$ and $0.2 \mathrm{~mm}(16,19-29) ; 30$ depicted not to scale.

Рис. 16-30. Anamastigona terraesanctae sp.n., паратип О с горы Meron: 16 - антенна; 17, 18 - метатергит 15, соответственно сбоку и сверху; 19 - нога $1 ; 20$ - нога $5 ; 21$ - нога $6 ; 22$ - нога $7 ; 23-$ нога $10 ; 24-$ нога $11 ; 25-27$ - передние гоноподы, соответственно сзади, сбоку и сзади и спереди; 28, 29 - задние гоноподы, соответственно сзади и спереди; 30 - увеличенное окончание среднетуловищной ноги. Масштаб 0,5 (17-18) и 0,2 мм (16, 19-29); 30 нарисован без масштаба. 
slightly separated (Figs 1, 2, $17 \& 18$ ). CIX (15) 0.6, MIX (15) 1.3; MA (15) 145 ; PIX (15) impossible to evaluate due to insufficiently developed paraterga. Ventral edge of $\sigma^{7}$ pleurotergum 7 normal, without apophyses, like most other pleuroterga with a faint ridge above at ventral bend (Fig. 1). Limbus missing.

Epiproct truncated caudally, with two spinnerets beneath; each paraproct with three long marginal setae; hypoproct semi-circular, with two long apical setae.

Legs slender, rather short, ca 0.9-1.0 times as short as midbody height in both sexes, devoid of tarsal papillae; all tibiae and tarsi with a long dorso-apical seta, main claws with a long filament ventrobasally and a couple of minute claws dorsobasally (Fig. 30); pairs 1 and 2 somewhat reduced as usual, with tarsal brushes ventrally (Fig. 19); $\sigma^{7}$ coxa 2 perforated by gonopore orifice; $\sigma^{7}$ pairs 3-7 increasingly incrassate (Fig. 1), their prefemora often distinctly bulged dorsoparabasally (Figs 4, 5, 20-22), O' prefemur 3 with an especially conspicuous, finger-shaped process directed forward; $\sigma^{7}$ legs 10 and 11 (Figs 6, 7, 23 \& 24) with coxal glands, $\sigma^{7}$ coxa 11 (Figs $7 \& 24$ ) with a conspicuous, long, distoventral, finger-shaped process.

Anterior gonopods (Figs 8-12, 25-27) fused basally, fused to sternum, both main arms subunciform and bent caudad; a broad, low, microspiculate sac-shaped structure present at base anteriorly (s); each arm distally consisting of a lateral, slightly shorter, simple, strongly chitinized, dentiform process (p) and a paramedian, densely spiculate/pilose/fringed/fimbriate, slightly higher, lamellar brush (b); caudal face with 1+1 lower, strongly chitinized, shelf-like colpocoxites (cp) about half as short as main arms, both cp being separated by a round foramen basally.

Posterior gonopods (Figs 13, 14, 28 \& 29) very strongly reduced; coxites (cx) placed on a typical sternum, higher, nearly independent, fused only at very base, papillate distally; each coxite crowned by a small tooth or knob, and flanked by a small, median, lamellar, membranous stalk (k) (= colpocoxite); telopodite (te) remnants strongly pigmented, black, located laterobasally on $\mathbf{c x}$.

Vulva (Fig. 15) densely setose, elongate; operculum with several particularly long setae, both valves subequal.

REMARKS. Adult males of this new species appear to be surface active only between February and May, as well as in November. Such a phenology pattern suggests two peaks of seasonal activity, one in spring, the second in late autumn (and in winter?). Furthermore, A. terraesanctae sp.n. seems to be confined to montane forest habitats. These features of biology and phenology are characteristic of such generally meso- to hygrophilous millipedes as the order Chordeumatida this species, genus, and family belong to. South of the Judean Mountains, in the Negev Desert, it definitely fails to occur, but east and southeast of the Galilee, in Syria and/or Jordan, it or a congener may well be found.
This new species shows only very modest variation. Thus, both gonopod pairs from various populations appear to vary only very little, slight differences concerning the shapes and armament of the colpocoxites (cp) and apical brushes (b) of the anterior gonopods, as well as of the colpocoxite (k), coxite (cx) and telopodite (te) of the posterior gonopods. This variation seems to be nothing more than individual, as revealed by our comparative analyses of several males representing the same micropopulations, e.g. those from Nahal Keziv, Mt Meron and Sansan.

\section{Anamastigona mauriesi sp.n.} Figs 31-45.

MATERIAL. Holotype $\sigma^{7}$ (ZMUM), Caucasus, Abkhazia, Duripsh, Cave Tarkiladze (= Cave Tarkila), 7.08.1939, leg. Y.A. Birstein.

Paratypes: $1 \overbrace{}^{7}, 1$ + 2 juv. (ZMUM), same locality, date and collector, together with holotype.

NAME. Honours Jean-Paul Mauriès, a globally renowned myriapodologist.

DIAGNOSIS. Difffers from congeners in structure of the posterior gonopods showing on both coxites a pair of long and thin processes (see key in Ćurčić et al. [2008]).

DESCRIPTION. Body with 30 segments (29 pleurotergites, including one apodous, + telson). Coloration uniformly yellowish, probably due to long preservation in alcohol (Fig. 31).

Length of holotype $27.3 \mathrm{~mm}$, vertical diameter of largest pleurotergite $1.9 \mathrm{~mm}$. Length of $O$ paratype $30.5 \mathrm{~mm}$, vertical diameter of largest pleurotergite 2.0 $\mathrm{mm}$.

Holotype with 19 , 9 paratype with 22 , ocelli arranged in four longitudinal rows. Head covered with short setae, $\sigma^{7}$ frons with neither tubercle nor impression. Labrum with 10 labral and four supralabral setae. Gnathochilarium: promentum large, triangular; stipites with 5-6 apical setae, 6-8 median setae, and numerous basal microsetae. Each lamella lingualis with a row of 5-7 setae. Length of antenna: $3.4 \mathrm{~mm}$ (holotype) or 3.8 $\mathrm{mm}$ ( $q$ paratype). Antennomeres 3-6 with three, one and four long sensory setae, respectively. Collum narrower than head.

Axial suture on pleurotega well-developed; stricture between pro- and metazona clearly visible. Paraterga well-developed, with closely positioned median and exterior macrochaetae (Figs 43 \& 44). Paraterga gradually reduced from segment 23 , disappearing on segments 28 and 29. Maximum length of macrochaetae on midbody pleurotergites $0.4 \mathrm{~mm}$ (holotype) or $0.45 \mathrm{~mm}$ († paratype).

Macrochaetal index CIX $(15)=0.42$ (holotype) or 0.40 ( $q$ paratype). Median index $\operatorname{MIX}(15)=1.07$ (holotype) or 0.90 ( 9 paratype). MA $(15) \sim 75^{\circ}$ (holotype) or $72^{\circ}$ ( $q$ paratype).

Epiproct with a pair of spinnerets and one transverse row of two setae; hypoproct subquadrate, with 


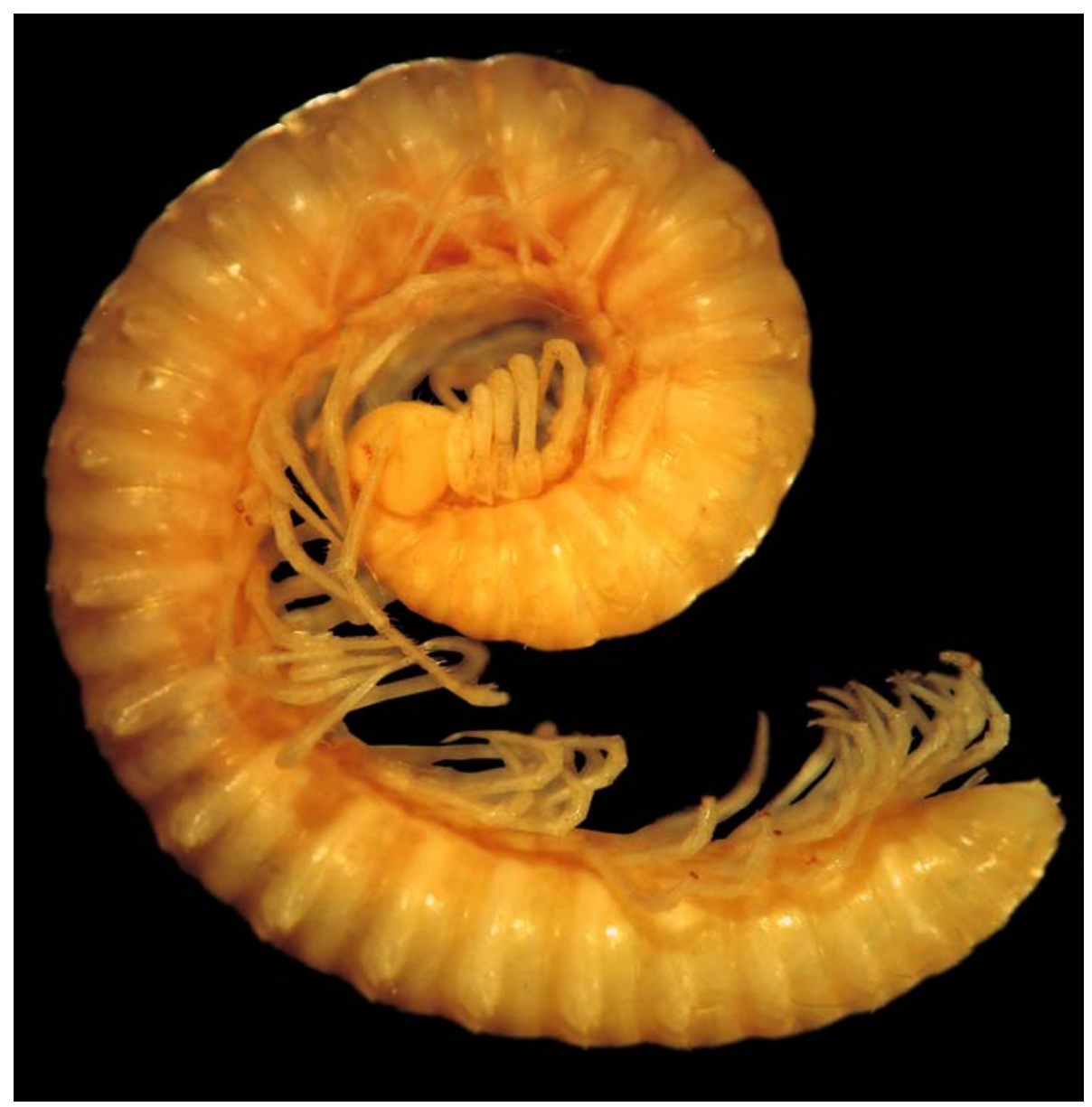

Fig. 31. Habitus of Anamastigona mauriesi sp.n., $0^{\top}$ paratype, lateral view, without scale. Рис. 31. Внешний вид Anamastigona mauriesi sp.n., паратип О’, сбоку, без масштаба.

two long apical setae; each paraproct with three long marginal setae.

Maximum length of midbody legs 2.3 (holotype) or $2.5 \mathrm{~mm}$ ( 9 paratype), i.e. in both sexes $1.2-1.3$ times as long as midbody height. $\sigma^{7}$ legs 3 and 4 with enlarged prefemora carrying massive, basal, outer outgrowths (Figs $32 \& 33$ ). $\sigma^{7}$ leg 5 with a long, outer, prefemoral, basal process (Fig. 34). $\sigma^{7}$ leg 6 with all podomeres elongated (Fig. 35). $0^{7}$ leg 7 largest and longest, with an unusual coxal process (Fig. 36). $\sigma^{7}$ legs 10 and 11 with coxal glands; coxa 10 with a horn (Figs $41 \& 37$ ). q leg 2 with a massive coxal bulbus (Fig. 38).

Anterior gonopods (Figs 42 \& 44) consisting of two lateral and a central part. Each lateral part consisting of a higher oral, apically sigmoid process (s) and a smaller caudal one (c) supplied with a denticulated posteromedian lamella (la). Central part wide, quadrangular, on its oral side carrying a long, thin, rodshaped, denticulated process (d).

Posterior gonopod (Fig. 43) consisting of two pairs of processes. Anterior pair representing a remnant of coxa, with a clear articulation with sternum, to be considered as coxites (cx). Apically, each coxite carrying a small telopodite remnant (te) and, posteromedially, two long coxal processes (pr). Posterior pair ovoid (k), with a canal-like structure, probably representing colpocoxites (derived from coxal glands).

Vulva (Fig. 45): operculum with $3+3$ long apical setae; bursa subovoid, wrinkled, covered with numerous short setae. Both vulvae covered with an unusual, massive, protecting, chitinous membrane $(\mathbf{c m})$.

REMARKS. This species seems to be troglophilic at most, with few adaptations to cave life, such as having both the antennae and walking legs elongated.

The anterior gonopods in A. mauriesi sp.n. show a pattern observed in almost all congeners. Generally, the anterior gonopods in Anamastigona consist of three elements: two lateral parts and a median one. Interspecific differences include either different shapes of these three parts or even their splitting, as well as the appearance of some additional processes, lamellae or similar structure [Ćurčić et al., 2008]. The posterior gonopods in A. mauriesi sp.n. are peculiar. Makarov et al. [2007] noted two groups of species differing substantially in the conformation of their posterior gonopods. In the first group (A. falcata, A. alba, A. lepenicae and $A$. 

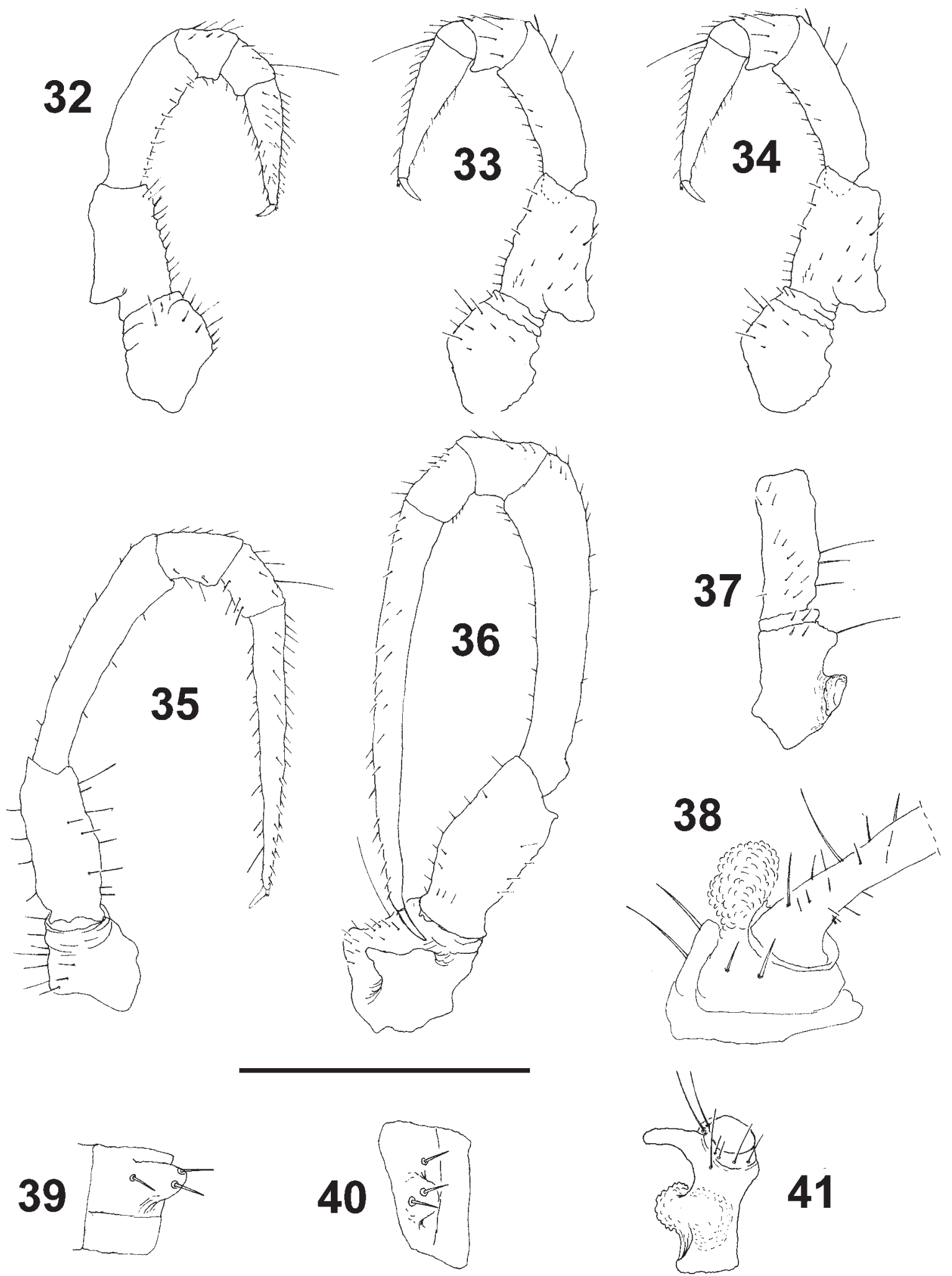

Figs 32-41. Anamastigona mauriesi sp.n., holotype (32-37, 39-41) and 9 paratype (38): $32-\operatorname{leg} 3 ; 33-\operatorname{leg} 4 ; 34-\operatorname{leg} 5 ; 35-$ leg $6 ; 36$ - leg $7 ; 37$ - coxa $11 ; 38$ - coxa $2 ; 39 \& 40$ - metatergum 15 , dorsal and lateral view, respectively; 41 - coxa 10 . Scale bar $1.0 \mathrm{~mm}$ for figures $32-38 \& 41$; figures $39-40$ drawn not to scale bar.

Рис. 32-41. Anamastigona mauriesi sp.n., голотип (32-37, 39-41) и паратип ф (38): 32 - нога 3; 33 — нога 4; 34 — нога 5; 35 нога $6 ; 36$ - нога $7 ; 37$ - кокса $11 ; 38$ - кокса $2 ; 39$ и 40 - метатергит 15 , соответственно сверху и сбоку; 41 - кокса 10. Масштаб 1,0 мм для рисунков 32-38 и 41; рисунки 39-40 даны без масштаба. 

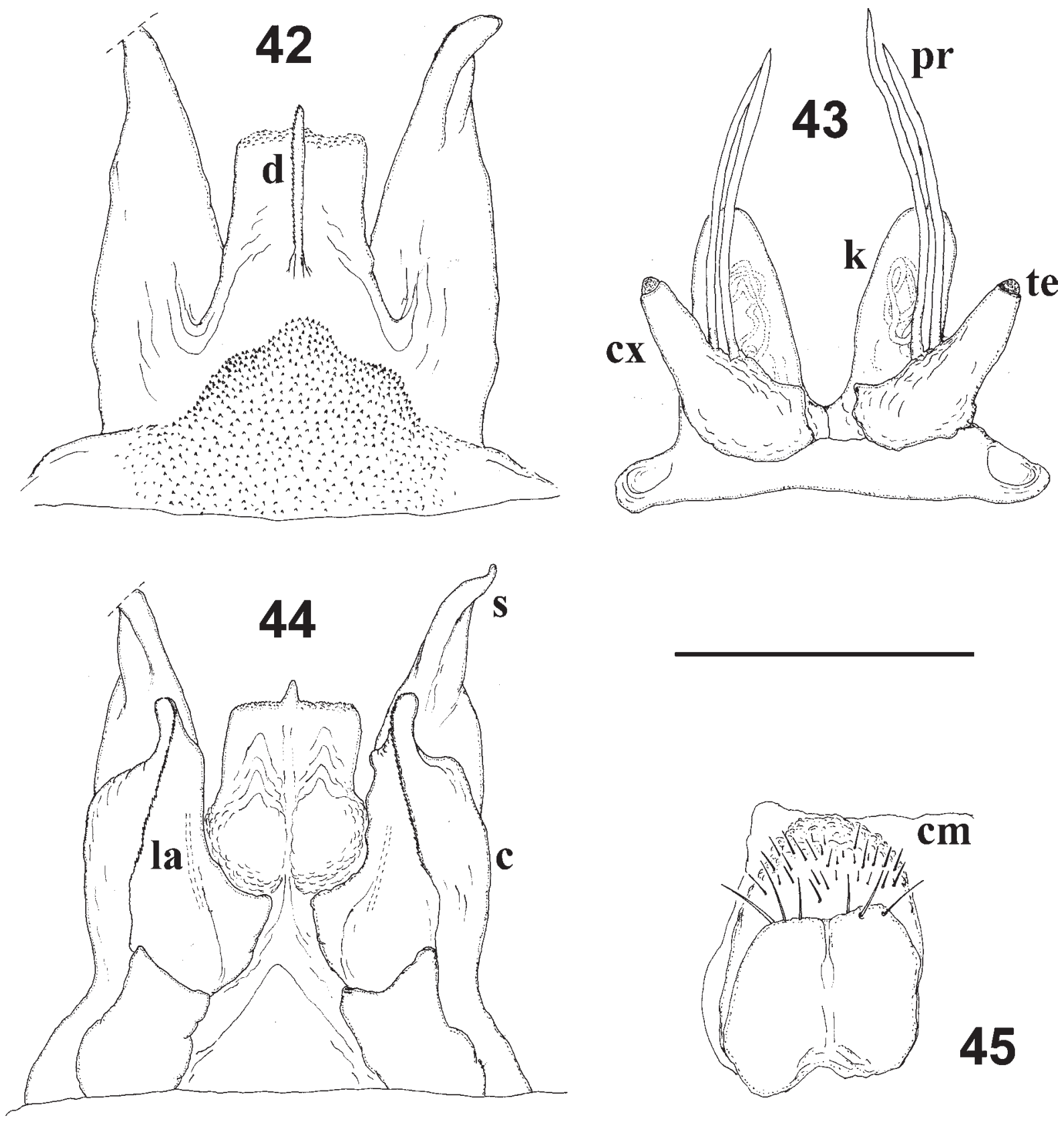

Figs 42-45. Anamastigona mauriesi sp.n., holotype (42-44) and $q$ paratype (45): 42, 44 — anterior gonopods, front view; 43 posterior gonopods, front view; 44 - anterior gonopods, caudal view; 45 - vulva, front view. Scale bar $0.5 \mathrm{~mm}$.

Рис. 42-45. Anamastigona mauriesi sp.n., голотип (42-44) и паратип + (45): 42, 44 - передние гоноподы, соответственно спереди и сзади; 43 - задние гоноподы, спереди; 45 - вульва, спереди. Масштаб 0,5 мм.

delcevi), the posterior gonopods are devoid even of telopodite rudiments, apparently a more derived condition. Species of the second group (A. pulchella, A. hispula, A. meridionalis, A. penicillata, A. penteliconica, A. bilselii, A. hauseri, A. matsakisi, A. mediterra$n e a$, and $A$. radmani) have a more or less clear telopodite remnant, obviously a plesiomorphic state. As regards $A$. mauriesi sp.n., it shows clear telopodite rudiments on top of the coxites, as opposed to the telopodite remains that are positioned more or less laterobasally on or close to the angiocoxites, these being enlarged or elongated as observed in all other Anamastigona species [Ćurčić et al., 2008]. In A. mauriesi $\mathrm{sp} . n$., the coxites represent remnants of the coxae which are still not modified to such a degree as to be termed angiocoxites. In our opinion, such a conformation of the posterior gonopods in the new Caucasian species is closer to the ancestral condition than in any 
other Anamastigona, including A. terraesanctae sp.n. On the other hand, A. mauriesi sp.n. shares the presence of pairs of flagelliform coxal processes with $\mathrm{Cau}$ caseuma Strasser, 1970, yet a monotypic genus containing the only species C. lohmanderi Strasser, 1970, from a cave near Sochi, western Caucasus, Russia [Strasser, 1970a]. Therefore, A. mauriesi sp.n. seems to occupy a deep, possibly basal position in the "Anamastigona clade" of anthroleucosomatids. A refined placement of $A$. mauriesi sp.n., as well as the betweengenus relationships within the Anthroleucosomatidae sensu lato, can be considerably clarified only when the definitely very complex and highly diverse Caucasian anthroleucosomatid fauna has become described in due detail.

ACKNOWLEDGEMENTS. We are most grateful to the Israeli-Russian interacademician exchange programme, which support allowed SG to collect in Israel in 2003 and 2007. Special thanks go to Prof. E. Nevo (Haifa, Israel), Prof. V. Chikatunov, Prof. T. Dayan, Dr V. Kravchenko, Dr Y. Mandelik and Dr O. Orlov (all Tel Aviv, Israel) for the help received during these collecting trips across Israel. The use of SEM by SM was partly supported by the Ministry of Science and Technological Development of Serbia (Grant \#173038). Prof. K. Makarov (Moscow, Russia) skillfully took the pictures. Both Mr. N. Likhitrakarn (Bangkok, Thailand) and Mr. H. Reip (Jena, Germany) provided invaluable technical assistance. Prof. Alessandro Minelli (Padua, Italy) most helpfully consulted SG on a linguistic problem. Prof. Richard L. Hoffman (Martinsville, Virginia, U.S.A.) kindly checked an advanced draft of the manuscript.

\section{References}

Attems K.G. 1902. Myriopoden von Kreta, nebst Beiträgen zur allgemeinen Kenntnis einiger Gattungen // Sitz.-Ber. Kaiserl. Akad. Wiss. Wien, Math.-naturw. Classe. Bd.111. Abth.1. S. $1-88$.

Ćurčić B.P.M., Makarov S.E., Lymberakis P.S. 2001. Diplopoda of Crete // Arch. Biol. Sci. Vol.53. Nos 3-4. P.99-108.

Ćurčić B.P.M., Makarov S.E., Tomić V.T., Mitić B.M., Ćurčić S.B., Dudić B.D., Lučić L.R., Jasnić N. 2008. On a new genus of endemic millipedes (Diplopoda: Chordeumatida: Anthroleucosomatidae) from the Balkan Peninsula // Zootaxa. No.1743. P.1-16.

Gulička J. 1967. Neue Höhlen-Diplopoden aus Bulgarien // Annot. Zool. Bot. No.42. P.1-5.

Lindner E.N., Reip H.S., Spelda J. 2010. Anamastigona pulchella (Silvestri, 1898) (Diplopoda: Chordeumatida: Anthroleucosomatidae) - ein für Deutschland neuer Tausendfüßer // Schubartiana. No.4. S.1-8.

Makarov S.E., Rada T., Rada B., Tomić V.T., Mitić B.M., Ćurčić B.P.M. 2007. Anamastigona radmani sp.n. (Diplopoda, Anthroleucosomatidae) from Croatia // Biologia (Zool.). Vol.62. No.5. P.581-587.

Mauriès J.-P. 1960. Diplopodes de la région toulousaine // Bull. Soc. Hist. Nat. Toulouse. T.95. P.100-104.

Mauriès J.P., Karamaouna M. 1984. Myriapodes-diplopodes nouveaux ou peu connus des îles Naxos, Paros et Antiparos (Cyclades, Grèce) // Biol. Gallo-Hell. Vol.9. No.1. P.51-59.

Mauriès J.-P., Golovatch S.I., Stoev P. 1997. The millipedes of Albania: recent data, new taxa; systematical, nomenclatural and faunistical review (Myriapoda, Diplopoda) // Zoosystema. Vol.19. No.2-3. P.255-292.

Spelda J. 2001. Review of the millipede genus Pterygophorosoma Verhoeff, 1897 (Diplopoda, Chordeumatida, Craspedosomatidae) // Andrias. Bd.15. S.29-48.

Strasser C. 1957/58. Diplopodi del Lazio // Boll. Soc. Adr. Sci. Nat. Trieste. Vol.49. No.9. P.137-170.

Strasser K. 1960. Diplopoden aus Alpen-, Apenninen- und Balkanländern // Fragm. Ent. Vol.3. Fasc.6. P.95-140.

Strasser C. 1962. Diplopoden aus Bulgarien und Jugoslawien // Senckenb. Biol. Bd.43. No.6. S.437-470.

Strasser K. 1970a. Über einige Diplopoden aus dem westlichen Kaukasus // Rev. suisse Zool. T.77. Fasc.1. P.199-205.

Strasser C. 1970b. Diplopodi della Sicilia e della Calabria // Mem. Mus. Civ. Stor. Nat. Verona. Vol.17. P.151-200 (for 1969).

Strasser K. 1970c. Über griechische Diplopoden (Griechenland, Korfu, Kreta, Ost-Ägäis) // Senckenberg. Biol. Bd.51. No.3/4. S.235-253.

Strasser K. 1973. Über Diplopoden Bulgariens, III // Ann. Zool. T.30. No.15. P.411-470

Strasser K. 1974. Über Diplopoda-Chilognatha Griechenlands // Rev. suisse Zool. T.81. Fasc.1. P.219-300.

Strasser K. 1975. Weiterer Beitrag zur Kenntnis der bulgarischen Diplopoden // Acta Zool. Bulg. Vol.3. P.70-77.

Verhoeff K.W. 1925. Neue Diplopoden-Beiträge. 95. DiplopodenAufsatz // Zool. Jarhb., Syst. Bd.50. S.61-122.

Verhoeff K.W. 1940. Über Diplopoden aus der Türkei // Rev. Fac. Sci. Univ. Istanbul, N.S. T.5. Fasc.1-2. P.1-49.

Responsible editor K.G. Mikhailov 